three random, 30-cm segments of each treatment during 7 weeks are shown in Fig. 1. The greatest number of emerged seedlings was obtained when Enersol was incorporated in the gel at seeding, followed by treatments using Ergostim or Agro-Lig in the gel. Although the gel-seeded treatments lost $25 \%$ or more of the emerged seedlings, more total harvested roots were produced than in the untreated control. Overcrowding of seedlings may have contributed to the high mortality. A combination of factors, including seedling survival, stand establishment, health of the crop, and plant spacing, contribute to high carrot yields.

Similar results in carrot weights and root numbers were obtained in Fall 1984 (Table $2)$. Seed germinated in water and seeded in gel again produced about twice as many carrots as using raw, untreated seed. Seeds germinated with biostimulants and then gelseeded produced $\approx 16 \%$ more carrots than gel-seeded without a biostimulant. The use of biostimulants also resulted in greater average root weights compared to when no biostimulant was used.

In contrast to other studies (Austin et al., 1969), seeds subjected to alternate imbibition and then drying (hardening) produced even fewer roots than seeds left untreated. Untreated and hardened seed did not differ significantly in average weight, total number of roots produced, or in plant vigor 21 days after seeding (Table 2). Seedling vigor was increased significantly by hardening the seed relative to untreated seed, but only up to 14 days after seeding. In addition, either gelseeded or biostimulant-treated seedlings were much more vigorous than untreated seed. There were highly significant differences in seedling emergence when untreated seed was compared to gel treatments and when use of biostimulants was compared to untreated seed (Table 2). Enersol and Agro-Lig treatments did not differ in the total number of roots harvested, although roots from treatments receiving Enersol were heavier.

Results of this study indicate gel-seeding combined with biostimulants can have a beneficial effect on carrot stand establishment and root growth, especially under stressful environmental conditions. Overseeding may be unnecessary when biostimulants are used due to the increased seedling emergence.

\section{Literature Cited}

Armstrong, F.B. 1979. Biochemistry. Oxford Univ. Press, New York.

Austin, R. B., P.C. Longden, and J. Hutchinson. 1969. Some effects of hardening carrot seed. Ann. Bet. 33:883-895.

Bryah, H.H. 1976. Response of tomatoes to seed and seedling applications of humates and alphaketo acids. Proc. Fla. State Hort. Soc. 89: 87-9.

Freeman, P.G. 1968. Some characteristics of natural and coal-derived humates: with bibliography. U.S. Bur. Mines Publ. IC-8376:191-201.

Himelrick, D. 1983. Effect of the biostimulant Ergostim on strawberries. Advances in strawberry prod. 2:18-20.

Lee, Y.S. 1976. Stimulation of plant growth by humic substances. Soil Sci. Soc. Amer. J. 40:876-879.

Linham, D.J. 1978. Humic acid and iron uptake by plants. Plant \& Soil 50:663-670.

Rauthan, B.S. and M. Schnitzer. 1981. Effects of soil fulvic acid on the growth and nutrient content of cucumber plants. Plant \& Soil 63:491495

Russell, E.W. 1961. Soil conditions and plant growth. 9th ed. Longman, Green, New York. Salter, P.J. 1978. Techniques and prospects for "Fluid drilling" of vegetable crops. Acts Hort. 72:101-107.

Schnitzer, M. and P.A. Poapst. 1967. Effects of soil humic acid compounds on root initiation. Nature (London) 213:598-599.

Senn, T.L. and A.R. Kingman. 1975. Report on humic research. Clemson Univ. Res. Ser. 106.

\title{
The Use of Vesicular-Arbuscular Mycorrhizae in Boston Fern Produc- tion: I. Effects of Peat-based Mixes
}

\author{
F. Ponton and Y. Piché ${ }^{1}$ \\ Centre de Recherche en Biologic Forestière, Faculté de Foresterie et de \\ Géomatique, University Laval, Ste-Foy, Qué. G1K 7P4, Canada
}

\author{
S. Parent and M. Caron \\ Centre de Recherche Premier Ltée, Rivière du Loup, B.P. 2600, Qué. \\ G5R 4C9, Canada
}

Additional index words. peatmoss, VAM formation, Boston fern, Glomus intraradices, Glomus vesiculiferum, growth enhancement

Abstract. The horticultural Boston fern [Nephrolepis exaltata (L.) Schott CV. Verona] was micropropagated in vitro using commercial techniques. Rooted plantlets were transferred into pots containing one of three test substrates made of peat and vermiculite and subsequently inoculated with one of two species of Glomus. Survival of uninoculated control plants growing on a black peat-based mix was less than that on a brown peat-based mix. Vesicular-arbuscular mycorrhizal (VAM) inoculation significantly increased survival on the former, but not the latter, substrate. The growth of roots was enhanced in brown peatmoss, but VAM colonization was faster with black peatmoss. Compared to uninoculated controls growing under the same fertilization regime, inoculated plants had significantly higher frond $P$ and $N$ concentration and also showed better frond and root growth. On a growth-increment basis, our results suggested that the brown peat-based mixed was more suitable for fungal activity and fern growth.

Beneficial interactions between vesiculararbuscular mycorrhizal (VAM) fungi and various woody ornamental plants (Nemec, 1987) or horticultural crops (Menge, 1983) are, in general, well-documented. Most of the experiments supporting these conclusions have been conducted in greenhouses

Received for publication 3 Feb. 1989. We thank Claude Camiré and Ken Wong for reviewing the manuscript, Gaétan Laberge for statistical assistance, and Madeleine Pelchat for her word processing skill. We acknowledge the Natural Sciences and Engineering Research Council of Canada for financial support. The cost of publishing this paper was defrayed in part by the payment of page charges. Under postal regulations, this paper therefore must be hereby marked advertisement solely to indicate this fact.

Address for correspondence: Centre de Recherche en Biologic Forestière, Faculté de foresterie et de géomatique, Université Laval, Ste-Fey, Qué. G1K 7P4, Canada. using pot cultures and sterilized soils. The use of mineral-type substrates was often preferred over organic substrates (Dehne and Backhauss, 1986; Plenchette et al., 1982). We found only a few investigations dealing with the potential use of peat-based substrates for VAM formation (Biermann and Linderman, 1983a; Biermann and Linderman, 1983b; Caron and Parent, 1988; Graham and Timmer, 1984; Graham and Timmer, 1985; Johnson and Hummel, 1986; Parent and Caron, 1987).

Little is known about the response of ferns to VAM inoculation (Cooper, 1975; Cooper, 1977; Stamps and Johnson, 1984), even though they are often mycorrhizal in the field (Berth and Kendrick, 1982; Boullard, 1957; Cooper, 1975). The VAM inoculation of ferns has been successful in various steam-sterilized mineral soils that contain organic inelusions (Cooper, 1975) and in a steamsterilized potting medium containing equal parts of sand, peat, and perlite (Stamps and 

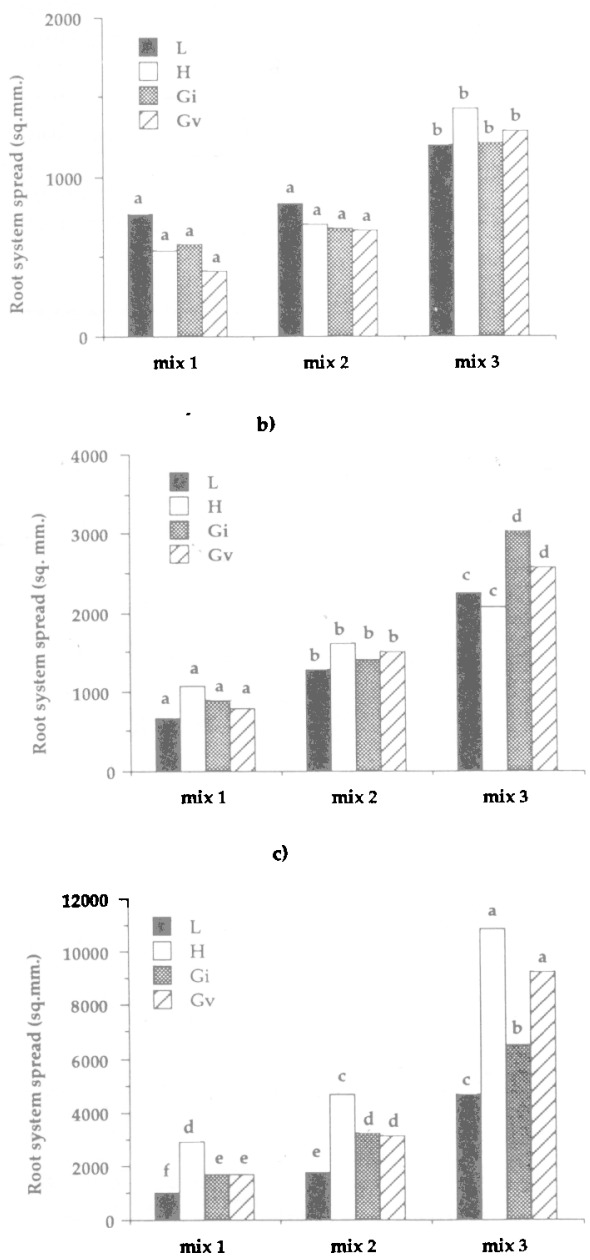

Fig. 1. Spread of Boston fern root system inoculated with Glomus intraradices (Gi) or G. vesiculiferum $(\mathrm{Gv})$ in the three peat-based mixes. Measurements were made 6 weeks (a), 12 weeks (b), and 18 weeks (c) after inoculation. Noninoculated controls were of type $\mathrm{L}$ or $\mathrm{H}$, which, respectively, had received low- and high-P fertilization. For each set of measurements, values with the same letters are not significantly different (Scott-Knott test, $P<0.05$ ).

Johnson, 1984). Observations by Boullard (1957) suggested that organic matter was essential to VAM formation in Pteridophytes, but no reports mention further observations of fern media preference for VAM inoculation. Boullard (1957) also studied seasonal variations in VAM infection of 'Rooseveltii' Boston fern, but no attempts were made to study fern growth responses due to VAM colonization.

Boston fern is a common household ornamental fern that has numerous cultivars prized for their variety of foliar shapes. Peatmoss substrates are suitable for commercial production of Boston ferns in greenhouses, and inoculation with VAM might increase production. The objectives of this study were to determine: 1) whether VAM formation on 'Verona' fern is influenced by peatmoss type, and 2) whether VAM colonization has an effect on host development.

Growth conditions for ferns. 'Verona' was micropropagated (at the CEGEP of Rivière-

Table 1. Hydrophysical propertiešof three amended peat-based mixes.

\begin{tabular}{cccccccc}
\hline \hline & & TPS & EA & AIR & EAW & WBC & - Residual \\
\cline { 3 - 8 } & $\begin{array}{c}\text { BD } \\
\text { Mix }^{y}\end{array}$ & $\left(\mathrm{~kg} \cdot\right.$ liter $\left.^{-1}\right)$ & \multicolumn{7}{c}{$[\%(\mathrm{v} / \mathrm{v})]$} \\
\hline 1 & $0.18 \mathrm{a}$ & $89.7 \mathrm{~b}$ & $1.5 \mathrm{~b}$ & $6.2 \mathrm{c}$ & $24.8 \mathrm{a}$ & $5.8 \mathrm{c}$ & 51.4 \\
2 & $0.16 \mathrm{ab}$ & $90.6 \mathrm{ab}$ & $3.4 \mathrm{~b}$ & $11.8 \mathrm{~b}$ & $23.6 \mathrm{a}$ & $7.6 \mathrm{a}$ & 44.2 \\
3 & $0.15 \mathrm{~b}$ & $91.5 \mathrm{a}$ & $10.4 \mathrm{a}$ & $15.1 \mathrm{a}$ & $26.7 \mathrm{a}$ & $6.7 \mathrm{~b}$ & 32.6
\end{tabular}

${ }^{2}$ For each property, values with the same letters are not significantly different (Duncan's multiple range test, $P<0.05)$. BD = Bulk density; TPS = total pore space; $\mathrm{EA}=$ entrapped air $=\mathrm{TPS}, 1 \mathrm{~cm}$; $\mathrm{AIR}=$ air capacity $=\mathrm{TPS}, 5 \mathrm{~cm} ; \mathrm{EAW}=$ easily available water $=5-5.0 \mathrm{~cm} ; \mathrm{WBC}=$ water buffering capacity $=50-100 \mathrm{~cm} ;$ Residual $=$ TPS $-(\mathrm{EA}+\mathrm{AIR}+\mathrm{EAW}+\mathrm{WBC})$.

"Mix 1: $75 \%$ black peatmoss and 25\% vermiculite (V); mix 2: $50 \%$ black peatmoss, $25 \%$ brown peatmoss and $25 \% \mathrm{~V} ; \operatorname{mix} 3: 75 \%$ brown peatmoss and $25 \% \mathrm{~V}$.

Table 2. Substrate fertility levels after 6, 12, and 18 weeks, according to guidelines for greenhouse growth media.

\begin{tabular}{lccc}
\multicolumn{1}{c}{ Ions $^{2}$} & & Harvest & \\
$\mathrm{NH}_{4}-\mathrm{N}$ & 1 & 2 & Low \\
$\mathrm{NO}_{3}-\mathrm{N}$ & Low & Low & Low \\
Potassium & Low & Low & Low \\
Calcium & Low & Low & Low \\
Magnesium & Low & Low & Low-acceptable \\
Phosphorus & Low & Low & Acceptable \\
Soluble salts & Low & Acceptable & Acceptable
\end{tabular}

${ }^{2} \mathrm{NH}_{4}-\mathrm{N}$ low-0-3 ppm; $\mathrm{NO}_{3}-\mathrm{N}$ Low-0-39 ppm; potassium low-0-59 ppm; calcium low-0-79 ppm; magnesium low-0-29 ppm, acceptable-30-69 ppm; phosphorus low-0-3 ppm, acceptable4-7 ppm soluble salts low-0-0.75 dS· $\mathrm{m}^{-1}$, acceptable: $0.75-1.49 \mathrm{ds} \cdot \mathrm{m}^{-1}$ [from Warncke (1980)].

du-Loup, Qué.) using in vitro techniques described by Henny et al. (1981). Rooted plantlets were transferred to $60-\mathrm{cm}^{3}$ pots containing test substrates and VAM inocula. Before introduction to greenhouse conditions, plantlets underwent 2 weeks of acclimatization under a mist with relative humidity varying from $100 \%$ to $70 \%$. Plantlets were maintained in these pots for 5 weeks before their transfer into $600-\mathrm{cm}^{3}$ pots. They were grown in the greenhouse with day/night average of $26 \mathrm{C} / 21 \mathrm{C}( \pm 3 \mathrm{C})$. High-pressure sodium vapor lamps were used to provide 15 to 20 klux light to extend the daylength to $16 \mathrm{hr}$. Plants were watered as needed and fertilized weekly with a commercial solution that contained (in $\mathrm{mg} \cdot \mathrm{liter}^{-1}$ ) 480 $\mathrm{MgSO}_{4} \cdot 7 \mathrm{H}_{2} \mathrm{O} ; 750 \mathrm{Ca}\left(\mathrm{NO}_{3}\right)_{2} \cdot 4 \mathrm{H}_{2} \mathrm{O}, 31.4$ 10N-52P-10K (Plant Products Co. Ltd., Bramalea, Ont.), and 55012N-0P-44K (Plant Products). This nutrient solution is based on the nutrient solution of Long Ashton (Hewitt, 1966) and is particularly weak in P. Pots of $60 \mathrm{~cm}^{3}$ and $600 \mathrm{~cm}^{3}$ received, respectively, 6 and $60 \mathrm{ml}$ of nutrient solution/week.

Test substrates. Black peatmoss (SL Regular) and brown peatmoss (Super SL) are Canadian sphagnum peat obtained from Premier Peat Moss Ltd. (Rivière-du-Loup, Qué.). Three kinds of peat-based mix were prepared by adding black and brown peatmoss to vermiculite. Mix 1 consisted of $75 \%$ black peatmoss and $25 \%$ vermiculite; mix 2 consisted of $50 \%$ black peatmoss, $25 \%$ brown peatmoss, and $25 \%$ vermiculite; mix 3 consisted of $75 \%$ brown peatmoss and $25 \%$ vermiculite. All mixes were limed to obtain a $\mathrm{pH}$ between 5.8 and 6.2 .

VAM inoculation. Glomus intraradices Schenk \& Smith and G. vesiculiferum
(Thaxter) Gerdemann \& Trappe were obtained from commercial VAM inocula produced by Centre de Recherche Premier (Rivière-du-Loup, Qué) using the pot culture method of Plenchette et al. (1982) with calcined montmorillonite clay as soilless medium. Samples of these two Glomus spp. have been deposited at the National Mycology Herbarium, Ottawa, Ont., and are identified, respectively, as DAOM 197198 and DAOM 198531. The inoculum was surfacesterilized with chloramine-T and streptomycin, as described by Mosse (1962). Experimental pots were inoculated with $1 \mathrm{~g}$ (fresh weight) of leek roots colonized by the appropriate fungus and placed below the roots. Inoculations were performed at the onset of the acclimatization period. Each of the two types of uninoculated controls received $1 \mathrm{~g}$ of nonmycorrhizal leek roots. Type L controls received low-P fertilization consisting of the basal nutrient solution that also was given to inoculated plants. Type $\mathrm{H}$ controls received high-P fertilization consisting of the basal nutrient solution supplemented with 114 mg of 0N-44P-0K/liter (Sudbury Laboratory, Sudbury, Mass.).

Experimental design. A randomized complete-block (six blocks) design was used to study the effect of VAM and peat-based substrates on Boston ferns. Each plant was an experimental unit. There were four treatments for each substrate: inoculated with mycorrhizal roots of leek containing chlamydospores of $\mathrm{G}$. intraradices $(\mathrm{Gi})$, inoculated with $\mathrm{G}$. vesiculferum $(\mathrm{Gv})$, type L (lowP) uninoculated controls, and type $\mathrm{H}$ (high$\mathrm{P})$ uninoculated controls. There were three replicates of each treatment in each block.

Harvesting and measurements. One ran- 


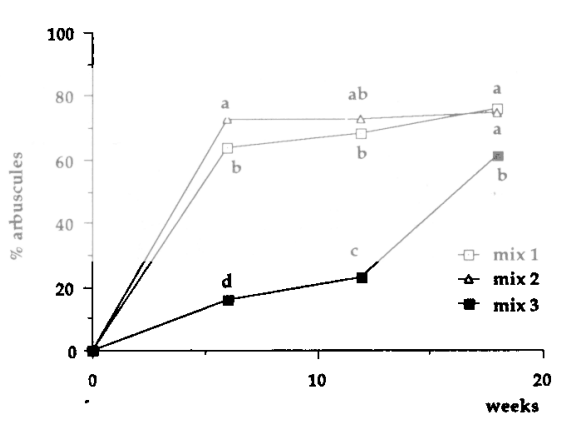

b)

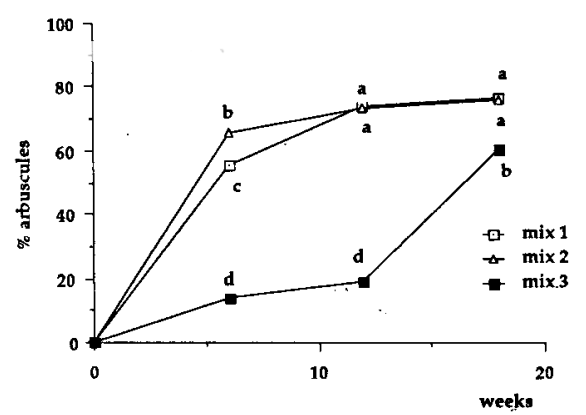

Fig. 2. Percentage of Boston fern root segments containing arbuscules of Glomus intraradices (a) and G. vesiculiferum(b) in the three peatbased mixes. For each harvest and each fungus, values with the same letters are not significantly different (Duncan's multiple range test, $P<$ $0.05)$.

dom replicate of each treatment in each block was harvested 6,12 , and 18 weeks after inoculation. The root system size was estimated visually using a series of rings ranging from 20 to $110 \mathrm{~mm}$ in diameter. Since arbuscules are considered to be the main organs for nutrient transfer from the fungus to the host plant (Cooper, 1984) and, since, for each vesicle seen, arbuscules were also present in our experiment, results were expressed as percentage of root segments containing arbuscules rather than the percentage of infection. Percentage of root segments containing arbuscules was determined using the gridline intersect method of Giovannetti and Mosse (1980) after clearing and staining the roots according to Brundrett et al. (1984).

Fronds were oven-dried for 3 days at $65 \mathrm{C}$ before dry weight was recorded. Hydrophysical properties of the substrates were measured following the technique of DeRouin et al. (1988). Nutrient concentration of substrate solutions was analysed by the saturated. medium extract method (SME) to determine their levels in comparison with guidelines for greenhouse growth media (Warncke, 1980). Frond P and N concentration was determined using the wet oxidation method of Parkinson and Allen (1975). Analysis of $\mathrm{N}$ was carried out using a Tecator Kjeltec autoanalyser 1030 and that of $\mathrm{P}$ using flow-injection analysis (Tecator analyser).

Statistical analysis. The homogeneity of
Table 3. Percent survival of Nephrolepis exaltata plantlets in several substrate mixes.

\begin{tabular}{llcc}
\hline \hline & \multicolumn{3}{c}{$\mathrm{Mix}^{\mathrm{z}}$} \\
\cline { 2 - 4 }$\quad$ Variables & 1 & 2 & 3 \\
\hline $\begin{array}{l}\text { Survival of uninoculated } \\
\text { plantlets( } \%)\end{array}$ & 73 & 80 & 90 \\
$\begin{array}{l}\text { Survival of inoculated } \\
\text { plantlets (\%) }\end{array}$ & 93 & 95 & 95 \\
$\begin{array}{l}\text { Probability that } \\
\text { inoculation did not } \\
\text { enhance survival } \\
\left(X^{2}, \mathrm{n}=80\right)\end{array}$ & 0.02 & 0.04 & 0.40 \\
\hline${ }^{2}$ See Table 1 for description of mixes.
\end{tabular}

Table 4. Analysis of variance of the percent root segments containing arbuscules.

\begin{tabular}{|c|c|c|c|}
\hline $\begin{array}{l}\text { Source of } \\
\text { variation }\end{array}$ & & $\begin{array}{l}\text { Sum of } \\
\text { squares }\end{array}$ & $\operatorname{Pr}>\mathrm{F}$ \\
\hline Blocks & 5 & 146 & $<0.3328$ \\
\hline Harvests $(\mathrm{H})$ & 2 & & \\
\hline $\mathrm{H}$ Lin & 1 & 9282 & $<0.0001$ \\
\hline H Quad & 1 & 404 & $<0.0001$ \\
\hline Substrates (S) & 2 & 35330 & $<0.0001$ \\
\hline substrat 1 vs. 3 & 1 & 23920 & $<0.0001$ \\
\hline substrat 2 vs. 1 and 3 & 1 & 11410 & $<0.0001$ \\
\hline Fungi (F) & 1 & 63 & $<0.1180$ \\
\hline $\mathrm{H} \operatorname{lin} \times \mathrm{S}$ & 2 & 5144 & $<0.0001$ \\
\hline $\mathrm{H}$ quad $\times \mathrm{S}$ & 2 & 1945 & $<0.0001$ \\
\hline $\mathrm{H} \operatorname{lin} \times \mathrm{F}$ & 1 & 172 & $<0.0104$ \\
\hline $\mathrm{H}$ quad $\times \mathrm{F}$ & 1 & 70 & $<0.0992$ \\
\hline $\mathrm{S} \times \mathrm{F}$ & 2 & 15 & $<0.7459$ \\
\hline $\mathrm{H} \operatorname{lin} \times \mathrm{S} \times \mathrm{F}$ & 2 & 54 & $<0.3426$ \\
\hline $\mathrm{H}$ quad $\times \mathrm{S} \times \mathrm{F}$ & 2 & 125 & $<0.0887$ \\
\hline Error & 85 & 2132 & $2 \quad---$ \\
\hline Total & 107 & 5488 & --- \\
\hline
\end{tabular}

variances for all variables was tested using the Burr-Foster procedure (Anderson and McLean, 1974). Logarithmic transformation was needed for the frond dry weight data to homogenize the variances among treatments. The variances for frond dry weight and root system spread were analyzed using analysis of variance (ANOVA) $(P=0.05)$ procedures for a $3 \times 3 \times 4$ factorial. Since arbuscules were absent in root segments of controls, the ANOVA for the percent of arbuscules was analyzed for a $3 \times 3 \times 2$ factorial (Steel and Torrie, 1980). In addition, ANOVA was used to discriminate the main sources of variation of the various characteristics tested in this study. For all characteristics studied, the relative variation due to harvest was mainly attributable to a significant linear effect (Tables 3-5). Duncan's multiple range test $(P<0.05)$ was used to illustrate differences between means. The percent survival of Boston fern plantlets in the different substrate mixes was analyzed following contingency tables. To obtain a better idea of the differences in the root system spread, treatment means were split into reasonably homogeneous groups and were analyzed following the cluster analysis method of Scott and Knott (1974). For the determination of frond $\mathrm{P}$ and $\mathrm{N}$ concentration for the first and second harvest, the six replicates of each treatment were subdivided and analyzed as two groups of three plants. For the third harvest, the six replicates were sub-
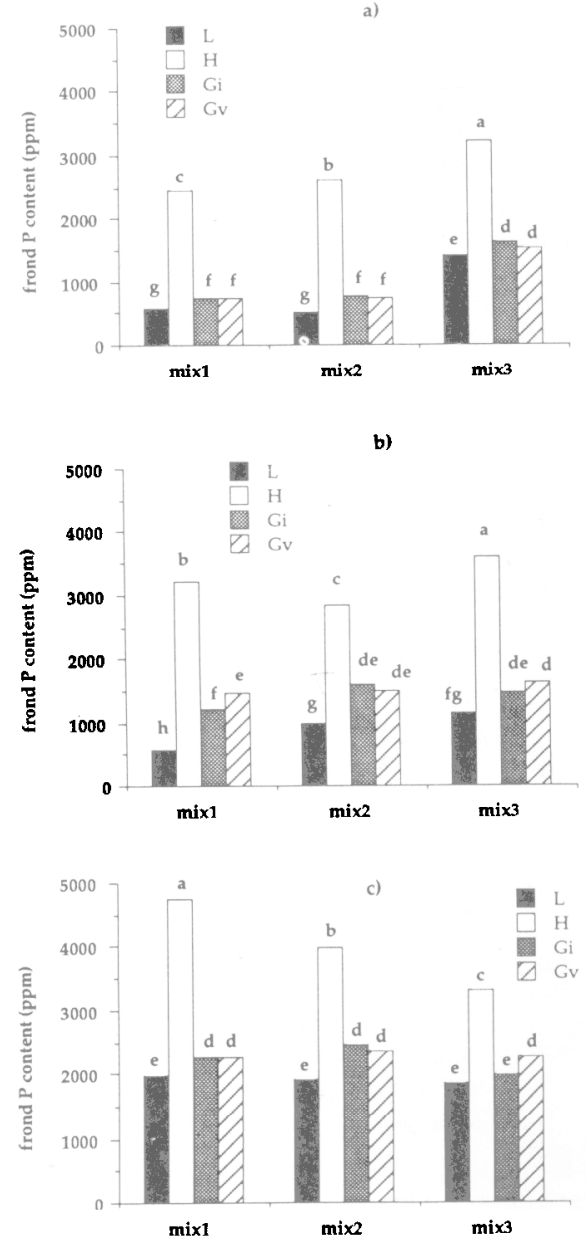

Fig. 3. Frond $\mathrm{P}$ content of Boston fern inoculated with Glomus intraradices $(\mathrm{Gi})$ or $G$. vesiculiferum $(\mathrm{Gv})$ in the three peat-based mixes. Measurements were made 6 weeks (a), 12 weeks (b), and 18 week a (c) after inoculation. Noninoculated controls were of type $\mathrm{L}$ or $\mathrm{H}$, which, respectively, had received low- and high-P fertilization. For each set of measurements, values with the same letters are not significantly different (Duncan's multiple range test, $\mathrm{P}<0.05$ ).

divided into three groups of two plants. Values of each hydrophysical property were the means of three replicates.

Substrate analysis. The peat-based mixes were evaluated for bulk density (BD), total pore space (TPS), entrapped air (EA), air capacity (AIR), easily available water (EAW), and water-buffering capacity (WBC). No significant differences occurred in the EAW of the substrates. However, mix 3 had the highest TPS and the lowest BD (but similar to mix 2), whereas mix 1 showed the opposite tendency for these measurements. Mix 2 had the highest WBC and mix 1 the lowest (Table 1).

During acclimatization, plants were maintained in soil near moisture saturation. Under these conditions, the available pore space occupied by air is represented by EA. Entrapped air values increased with increasing proportion of brown peatmoss in the substrate mix. Mix 3 was at least three times more aerated than the other mixes, and it also had significantly greater water-free po- 


\begin{tabular}{|c|c|c|c|c|c|}
\hline \multirow{3}{*}{$\begin{array}{c}\text { source } \\
\text { of } \\
\text { variation }\end{array}$} & \multirow[b]{3}{*}{$\mathrm{df}$} & \multicolumn{2}{|c|}{ Root system spread } & \multirow{2}{*}{\multicolumn{2}{|c|}{ Frond dry wt }} \\
\hline & & \multirow{2}{*}{$\begin{array}{l}\text { Sum of } \\
\text { squares } \\
\text { (millions) }\end{array}$} & \multirow[b]{2}{*}{$\operatorname{Pr}>F$} & & \\
\hline & & & & $\begin{array}{l}\text { Sum of } \\
\text { squares }\end{array}$ & $\operatorname{Pr}>\mathrm{F}$ \\
\hline Blocks & 5 & 4.826 & $<0.0970$ & 0.62 & $<0.0001$ \\
\hline Harvests $(\mathrm{H})$ & 2 & --- & -- & -- & --- \\
\hline $\mathrm{H}$ Lin & 1 & 420.7 & $<0.0001$ & 283.4 & $<0.0001$ \\
\hline H Quad & 1 & 45.31 & $<0.0001$ & 0.80 & $<0.0001$ \\
\hline Substrates (S) & 2 & 299.8 & $<0.0001$ & 88.68 & $<0.0001$ \\
\hline substrat 1 vs. 3 & 1 & 277.7 & $<0.0001$ & 87.19 & $<0.0001$ \\
\hline substrat 2 vs. 1 and 3 & 1 & 22.12 & $<0.0001$ & 1.49 & $<0.0001$ \\
\hline Fungi (F) & 3 & 45.31 & $<0.0001$ & 13.70 & $<0.0001$ \\
\hline fungi 3 vs. 4 & 1 & 1.472 & $<0.0907$ & 0.09 & $<0.0405$ \\
\hline fungi 1 vs. 3 and 4 & 1 & 15.62 & $<0.0001$ & 5.60 & $<0.0001$ \\
\hline fungi 2 vs. 1,3 , and 4 & 1 & 2822 & $<0.0001$ & 8.01 & $<0.0001$ \\
\hline $\mathrm{H} \operatorname{lin} \times \mathrm{S}$ & 2 & 184.0 & $<0.0001$ & 1.01 & $<0.0001$ \\
\hline $\mathrm{H}$ quad $\times \mathrm{S}$ & 2 & 29.06 & $<0.0001$ & 1.24 & $<0.0001$ \\
\hline $\mathrm{H} \operatorname{lin} \times \mathrm{F}$ & 3 & 65.56 & $<0.0001$ & 3.46 & $<0.0001$ \\
\hline $\mathrm{H}$ quad $\times \mathrm{F}$ & 3 & 18.83 & $<0.0001$ & 0.85 & $<0.0001$ \\
\hline$S \times F$ & 6 & 15.10 & $<0.0001$ & 3.68 & $<0.0001$ \\
\hline $\mathrm{H} \operatorname{lin} \times \mathrm{S} \times \mathrm{F}$ & 6 & 19.37 & $<0.0001$ & 1.07 & $<0.0001$ \\
\hline $\mathrm{H}$ quad $\times \mathrm{S} \times \mathrm{F}$ & 6 & 15.53 & $<0.0001$ & 1.95 & $<0.0001$ \\
\hline Error & 175 & 89.00 & --- & 3.57 & --- \\
\hline Total & 215 & 1252 & --- & 404.1 & --- \\
\hline
\end{tabular}

${ }^{2}$ Fungi 1: control type L (low-P); fungi 2: control type $\mathrm{H}$ (high-P); fungi 3: Glomus intraradices; fungi 4: Glomus vesiculiferum.

Table 6. Analysis of variance of the frond $\mathrm{P}$ concentration and the frond $\mathrm{N}$ concentration.

\begin{tabular}{|c|c|c|c|c|c|}
\hline \multirow{3}{*}{$\begin{array}{c}\text { Source } \\
\text { of } \\
\text { variation }\end{array}$} & \multirow[b]{3}{*}{ df } & \multicolumn{2}{|c|}{$\mathrm{P}$ concn } & \multirow{2}{*}{\multicolumn{2}{|c|}{$\mathrm{N}$ concn }} \\
\hline & & & & \\
\hline & & $\begin{array}{l}\text { squares } \\
\text { (millions) }\end{array}$ & $\operatorname{Pr}>F$ & $\begin{array}{l}\text { Sum of } \\
\text { squares }\end{array}$ & $\operatorname{Pr}>F$ \\
\hline \multicolumn{6}{|l|}{ Harvests $(\mathrm{H})$} \\
\hline $\mathrm{H}$ Lin & 1 & 22.25 & $<0.0001$ & 3.28 & $<0.0001$ \\
\hline H Quad & 1 & 0.9328 & $<0.0001$ & 0.11 & $<0.0001$ \\
\hline Substrates (S) & 2 & 0.9237 & $<0.0001$ & 0.92 & $<0.0001$ \\
\hline substrat 1 vs. 3 & 1 & 0.6922 & $<0.0001$ & 0.90 & $<0.0001$ \\
\hline substrat 2 vs. 1 and 3 & 1 & 0.2315 & $<0.0001$ & 0.03 & $<0.0052$ \\
\hline Fungi $(\mathrm{F})$ & 3 & 54.82 & $<0.0001$ & 1.30 & $<0.0001$ \\
\hline fungi 3 vs. 4 & 1 & 0.01507 & $<0.0772$ & 0.06 & $<0.0001$ \\
\hline fungi-1 vs. 3 and 4 & 1 & 1.890 & $<0.0001$ & 1.05 & $<0.0001$ \\
\hline fungi 2 vs. 1,3 , and 4 & 1 & 52.91 & $<0.0001$ & 0.20 & $<0.0001$ \\
\hline $\mathrm{H} \operatorname{lin} \times \mathrm{S}$ & 2 & 4.898 & $<0.0001$ & 0.72 & $<0.0001$ \\
\hline $\mathrm{H}$ quad $\times \mathrm{S}$ & 2 & 0.1021 & $<0.0001$ & 0.09 & $<0.0001$ \\
\hline $\mathrm{H}$ lin $\times \mathrm{F}$ & 3 & 0.07374 & $<0.0030$ & 0.90 & $<0.0001$ \\
\hline $\mathrm{H}$ quad $\times \mathrm{F}$ & 3 & 0.2989 & $<0.0001$ & 0.31 & $<0.0001$ \\
\hline $\mathrm{S} \times \mathrm{F}$ & 6 & 1.174 & $<0.0001$ & 0.24 & $<0.0001$ \\
\hline $\mathrm{H} \operatorname{lin} \times \mathrm{S} \times \mathrm{F}$ & 6 & 0.9284 & $<0.0001$ & 0.39 & $<0.0001$ \\
\hline $\mathrm{H}$ quad $\times \mathrm{S} \times \mathrm{F}$ & 6 & 0.7368 & $<0.0001$ & 0.28 & $<0.0001$ \\
\hline Error & 48 & 0.2218 & --- & 0.15 & --- \\
\hline Total & 83 & 88.85 & --- & 8.77 & --- \\
\hline
\end{tabular}

${ }^{2}$ Fungi 1: control type L (low-P); fungi 2: control type H (high-P); fungi 3: Glomus intraradices; fungi 4: Glomus vesiculiferum.

rosity under normal watering conditions (AIR) (Table 1).

Finally, the substrate solution analysis revealed that $\mathrm{NO}_{3}-\mathrm{N}$ and $\mathrm{NH}_{4}-\mathrm{N}$ levels were low for the complete duration of the experiment, while $\mathrm{PO}_{4}-\mathrm{P}$ in solution varied from low to acceptable conditions. In general, there was little difference between treatments and mixtures for all ions shown in Table 2. At the end of the experiment, the solution $\mathrm{pH}$ ranged from 6.5 to 6.9 , with higher values in mix 3 and lower ones in mix 1, but with no significant differences between treatments for a given substrate.

Percent survival. Under our conditions, mix 3 provided better root development for inoculated and uninoculated plantlets (Fig.
1) and better plant survival percentage for uninoculated plantlets (Table 3). Although survival frequency in mix 3 was not significantly increased by VAM inoculation, it was significantly increased in mixes 1 and 2 (Table 3).

Percentage of root segments containing arbuscule. No real assessment was made on the extent of colonization during the acclimatization, but some plantlets were removed to check for the presence of the endophyte. Presence of the endophyte was noted only in mixes 1 and 2. Percent root segments colonized by VAM mainly depended on the substrate, to a lower extent on the harvest, but not on the fungal inoculation (Table 4). Lowest values were consistently observed in

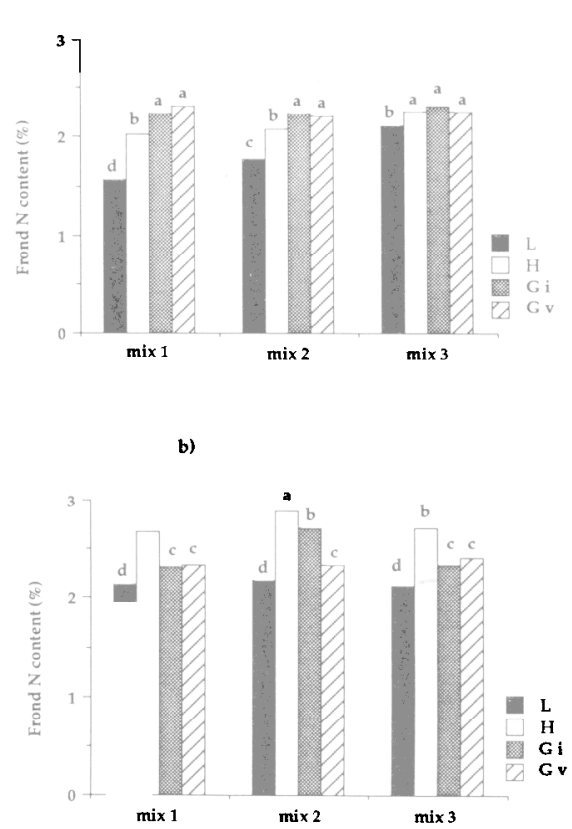

Fig. 4. Frond $\mathrm{N}$ content of Boston fern inoculated with Glomus intraradices (Gi) or G. vesiculiferum $(\mathrm{Gv})$ in the three peat-based mixes. Measurements were made 12 weeks (a) and 18 weeks (b) after inoculation. Noninoculated controls were of type $\mathrm{L}$ or $\mathrm{H}$, which, respectively, had received low- and high-P fertilization. For each set of measurements, values with the same letters are not significantly different (Duncan's multiple range test, $P<0.05$ ).

mix 3 and similar patterns of VAM colonization were observed in mixes 1 and 2 (Fig. 2 ). In mixes 1 and 2, VAM colonization occurred rapidly during the first 6 weeks and $\approx 70 \%$ of root segments contained arbuscules after 18 weeks. In mix 3, VAM colonization was initially slow, but increased rapidly after week 12 to achieve $\approx 60 \%$ colonization at week 18. Vesicle development in all mixes remained low, with $<20 \%$ of root segments containing vesicles after 18 weeks.

Effects on root growth. Root system spread mainly depended on the harvest and the substrate (Table 5). In accordance with the low value of the sum of squares, the fungi had only a small effect on root growth (Table 5). In comparing the respective treatments, there were no significant differences between mixes 1 and 2 at the first harvest, but root system spread was thereafter consistently lower in mix 1 (Fig. 1). Root system spread was consistently greatest in mix 3 . At the third harvest, mycorrhizal treatments generally showed values of root system spread lower than those of control type $\mathrm{H}$ but higher than those of control type L in each of the substrates (Fig. $1 c)$.

Effects of frond development. According to the sum of squares values of the treatments, $\mathrm{P}$ concentration in fronds was mainly dependent on fungal inoculation and harvest (Table 6). It increased with time, and mycorrhizal treatments yielded lower values than 
Table 7. Analysis of variance of the growth increment between the second and third harvest.

\begin{tabular}{lccc}
\multicolumn{1}{c}{$\begin{array}{c}\text { Source of } \\
\text { variation }\end{array}$} & df & $\begin{array}{c}\text { Sum of } \\
\text { squares } \\
\text { (millions) }\end{array}$ & Pr $>$ F \\
\hline Blocks & 5 & 0.3198 & $<0.2065$ \\
Substrates (S) & 2 & 38.48 & $<0.0001$ \\
substrat 1 vs. 3 & 1 & 36.27 & $<0.0001$ \\
substrat 2 vs. 1 and 3 & 1 & 2.213 & $<0.0001$ \\
Fungi (F) & 3 & 19.24 & $<0.0001$ \\
fungi 3 vs. 4 & 1 & 0.1554 & $<0.0619$ \\
fungi 1 vs. 2 & 1 & 19.08 & $<0.0001$ \\
fungi 1 and 2 vs. 3 and 4 & 1 & 0.001901 & $<0.0338$ \\
S $\times$ F & 6 & 3.554 & - \\
Error & 55 & 2.353 & -- \\
Total & 71 & 63.94 & - \\
\hline
\end{tabular}

${ }^{2}$ Fungi 1: control type L (low-P); fungi 2: control type $\mathrm{H}$ (high-P); fungi 3: Glomus intraradices; fungi 4: Glomus vesiculiferum.

those of control I-I, but higher than those of control L (Fig. 3). The effect of substrate type was negligible, but showed a significant interaction with time and with fungal inoculation (Table 6). At the first harvest, plants
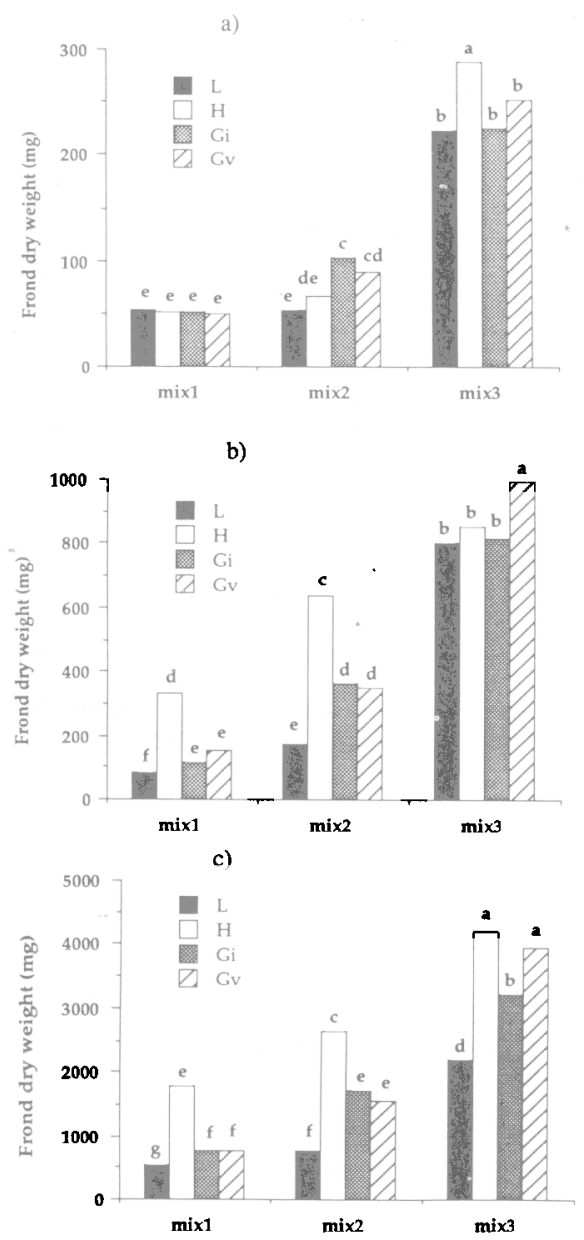

Fig. 5. Frond dry weight (mg/plant) of Boston fern inoculated with Glomus intraradices $(\mathrm{Gi})$ or G. vesculiferum $(\mathrm{Gv})$ in the three peat-based mixes. Measurements were made 6 weeks (a), 12 weeks (b), and 18 weeks (c) after inoculation. Noninoculated controls were of type L or $\mathrm{H}$, which, respectively, had received low- and high-P fertilization. For each set of measurements, values with the same letters are not significantly different (Duncan's multiple range test, $P<0.05)$. grown in mix 3 had the highest frond $\mathrm{P}$ concentration, whereas those grown in mixes 1 and 2 had very similar and low values (Fig. 3a). Phosphorus concentration thereafter increased substantially in plants cultivated in mixes 1 and 2, but no change occurred in plants grown in mix 3 (Fig. 3b). Frond $\mathrm{P}$ concentration in mycorrhizal plants was always significantly greater than control $\mathrm{L}$ for ices in mix 3 (Fig. 3); the fungi effect varied for a given substrate (Table 6).

Frond $\mathrm{N}$ concentration (Table 6) mainly depended on the harvest, the fungal treatment, and the interactions between them. It was generally the same for all treatments after 6 weeks (data not shown). After 12 and 18 weeks, mycorrhizal treatments showed higher frond $\mathrm{N}$ concentration than control $\mathrm{L}$ grown on the same substrate (Fig. 4). The effect of substrate and its interaction with harvest were less important (Table 6). However, depending on substrate and harvest, $\mathrm{N}$ concentration in control $\mathrm{H}$ plants was lower (Fig. 4a) or higher (Fig. 4b) than that in mycorrhizal plants.

Frond dry weight mainly depended on the harvest and the substrate (Table 5), All the interactions for this characteristic were of little importance in the model due to their low values of sum of squares. While the effect

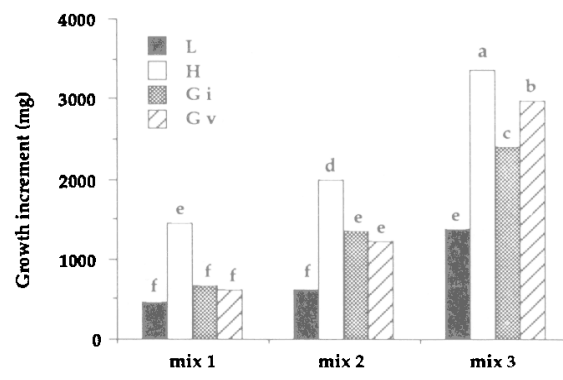

Fig. 6. Growth increment, between second and third harvests, of Boston fern inoculated with Glomus intraradices (Gi) or G. vesiculiferum $(\mathrm{Gv})$ in the three peat-based mixes. Noninoculated controls were of type $\mathrm{L}$ or $\mathrm{H}$, which, respectively, had received low- and high-P fertilization. Each treatment was replicated six times. Values with the same letters arc not significantly different (Duncan's multiple range test, $P<0.05)$. the same substrate, except for $G$. intrar-ad- of fungi in mixes 1 and 2 (Fig. 5b) was evident after 12 weeks, this effect in mix 3 was only conclusive after 18 weeks (Fig. SC).

The growth increment in terms of dry weight of fronds between the 12th and 18th weeks for all treatments is presented in Fig. 6. It depended mainly on substrate and fungal treatment (Table 7). Growth increment was generally lowest on mix 1 and highest on mix 3 (Fig 6). In comparison with control $\mathrm{H}$ and control L. mycorrhizal effects were evident in mixes 2 and 3, but not in mix 1 . Growth increments in control H were significantly higher than those in mycorrhizal treatments.

In our experiment, the positive effect of endomycorrhizae on plant survival was more evident in substrate mixes 1 and 2, where there was less root aeration than in mix 3 (Table 1). Although survival of uninoculated plants in mixes 1 and 2 was good, the results nevertheless suggest that aeration is limiting in these two mixes. Barrows and Roncadori (1977) reported that poinsettia (Euphorbia pulcherrima Wind.) cuttings inoculated with a VAM fungus survived better than uninoculated controls, but that this relationship tended to disappear when culture conditions were made from more favorable for the plant.

Under our conditions, peat-based mix 3 appeared more suitable for root respiration, which, in turn, may have stimulated fern root development (Fig. 1). Stolzy et al. (1961) have demonstrated that the size of a root system generally increases with increasing oxygen availability. Root aeration may also be responsible for the relatively better survival of noninoculated plantlets in mix 3 (Table $3)$.

Saif (1981) stated that $\mathrm{O}_{2}$ concentration in the soil atmosphere generally has a stronger effect on physiological activity of mycorrhizae than on the degree of infection. He also demonstrated that soil aeration must be at a certain level before benefits from endomycorrhizal symbiosis are maximized (Saif, 1981; Saif, 1983). Based on fern growth (Figs. 5 and 6), our results suggested that VAM fungi are indeed more efficient in a well-aerated substrate.

In addition to root development, soil conditions can also influence the ability of VAM fungi to infect and stimulate fern plants. In P-deficient soils, Cooper $(1975,1977)$ showed significant growth enhancement of various Leptosporangiate ferns by VAM. It is therefore possible that the delayed increase of VAM infection with mix 3 was due to changes in $\mathrm{P}$ availability (Fig. 2). Plants in mix 3 grew well during the first 12 weeks, despite relatively poor VAM colonization. This growth may have exhausted available $\mathrm{P}$, thereby favoring increased VAM colonization after week 12 . This colonization subsequently provided excellent fern growth (Fig. 6).

VAM colonization progresses in a sigmoid manner, similar to the growth of many biological populations (Saif, 1977; Sutton, 1973). Our data suggest that the lag phase of mycorrhizal colonization is greatly prolonged in the most-aerated substrate (mix 3 ). An analogous study reported that VAM in- 
fection on crop plants maybe delayed if their root system is extending too rapidly (Black and Tinker, 1979). Furthermore, high P concentration in the host plant also leads to reduced VAM infection (Menge et al., 1978; Sanders, 1975), and P status seems to be the main factor determining VAM formation on plants (Mosse, 1973). In light of these considerations, rapid root development (Fig. la) and high $\mathrm{P}$ concentration (Fig. 3a) in plantlets grown on mix 3 could explain the relatively few root segments containing arbuscules at first harvest (Fig. 2).

The influence of VAM on N nutrition has received little attention (Smith et al., 1985). In our experiment, mycorrhizal treatments yielded a higher frond $\mathrm{N}$ concentration than that in control L. Depending on the substrate and the harvest, control $\mathrm{H}$ fronds had lower or higher $\mathrm{N}$ concentration' than fronds of mycorrhizal plants. Under the low levels of nutrient concentration of substrate solutions, particularly $\mathrm{N}$, in our experiment (Table 2), the plants would use nearly all the available $\mathrm{N}$ sources. The predominant form of assimilable $\mathrm{N}$ was the readily mobile $\mathrm{NO}_{3}$, but $\mathrm{NH}_{4}^{+}$is supposed to also be present. Furthermore, ammonium salts are readily produced during microbial digestion (Brady, 1984). However, $\mathrm{NH}_{4}^{+}$may be less available because vermiculite and organic matter are known to fix ammonium into forms that are relatively unavailable to higher plants (Brady, 1984). Recent findings indicated that VAM fungi are able to assimilate $\mathrm{NH}_{4}^{+}$(Barea et al., 1987; Smith et al., 1985), but it is unlikely that $\mathrm{NO}_{3}$ uptake is increased by VAM (Rhodes and Gerdemann, 1980). A contribution of VAM to plant growth may therefore include making $\mathrm{NH}_{4}^{+}$more available to the plant. Ames et al. (1984) have suggested that VA mycorrhizal plants could derive $\mathrm{N}$ from a source that was less available to nonmycorrhizal plants.

In terms of frond development and root growth, G. vesiculiferum was more effective than $G$. intraradices in mix 3 only (Figs. 1c, $3 c, 5 c$, and 6). Significant interactions between fungal strains and soil have also been reported previously (Johnson, 1977; Mosse, 1972; Powell, 1982), suggesting that specific inoculants may have to be chosen for different soil types. Glomus vesiculiferum seems to be more adapted to the well-aerated conditions of mix 3 than $G$. intraradices.

Future use of VAM fungi in greenhouse production of ferns requires potting media that are compatible with the appropriate fungus and host. Our results indicate that a brown peat-based mix can greatly prolong the lag phase of VAM colonization, as compared with a black peat-based mix. Better growth results for ferns 'in mix 3 indicate that the brown peatmoss was more favorable for fern growth and for the physiological activity of VAM. We compared mycorrhizal treatments with two types of uninoculated controls to evaluate the growth effects of VAM on Boston fern plantlets. We observed that inoculated plants had higher frond $\mathrm{P}$ and $\mathrm{N}$ concentration, higher frond dry weights and a larger root system spread than uninoculated plants growing in the same low-P fertilization regime. These results re-emphasized the benefit of VAM inoculation to plants growing under stress conditions, such as a low-P fertilization regime. In general, for all growth characteristics tested, uninoculated plants in a P-supplemented fertilization regime grew better than the mycorrhizal treatments. It would be of interest under critical stress conditions (low air humidity, low soil moisture, and soil pathogens) to determine if the supplemented $\mathrm{P}$ fertilization regimen could be as efficient as mycorrhizal treatments.

\section{Literature Cited}

Ames, R. N., L.K. Porter, T.V. St-John, and C.P.P. Reid. 1984. Nitrogen sources and "A" values for vesicular-arbuscular and non-mycorrhiza sorghum grown at three rates of ${ }^{15} \mathrm{~N}$-ammonirim sulphate. New Phytol. 97:269-276.

Anderson, V.L. and R.A. McLean. 1974. Design of experiments. A realistic approach. Marcel Dekker, New York.

Barea, J. M., C. Azcon-Aguilar, and R. Azcon. 1987. Vesicular-arbuscular mycorrhiza improve both symbiotic $\mathrm{N}$, fixation and $\mathrm{N}$ uptake from soil as assessed with a ${ }^{15} \mathrm{~N}$ technique under field conditions. New Phytol. 106:717-725.

Barrows, J.B. and R.W. Roncadori. 1977. Endomycorrhizal synthesis by Gigaspora margarita in poinsettia. Mycologia 69:1173-1184.

Berth, S.M. and.. B. Kendrick. 1982. Vesiculararbuscular mycorrhizae of southern Ontario ferns and ferns-a! lies. Mycologia 79:769-776.

Biermann, B.J. and R.G. Linderman. 1983a. Effect of container plant growth medium and fertilizer phosphorus on establishment and host growth response to vesicular-arbuscular mycorrhizae. J. Amer. Soc. Hort. Sci. 108:962-971.

Biennann, B.J. and R.G. Linderman. 1983b. Increased geranium growth using pretransplant inoculation with a mycorrhizal fungus. J. Amer. Soc. Hort. Sci. 108:972-976.

Black, R. and P.B. Tinker. 1979. The development of endomycorrhizal root systems: IL Effect of agronomic factors and soil conditions on the development of vesicular-arbuscular mycorrhizal infection in Barley and on the endophyte spore density. New Phytol. 83:401-413.

Boullard, B. 1957. La mycotrophie chez les Ptéridophytes. Sa fréquence, ses caractères, sa signification. Le Botaniste, sér. XLI:1-185.

Brady, N.C. 1984. The nature and properties of soils. Macmillan, New York.

Brundrett, M. C., Y. Piché, and R.L. Peterson. 1984. A new method for observing the morphology of vesicular-arbuscular mycorrhizae. Can. J. Bet. 62:2128-2134.

Caron, M. and S. Parent. 1988. Definition of a peat-lite medium for the use of vesicular-arbuscular mycorrhizae (VAM) in horticulture. Acts Hort. 221:289-294.

Cooper, K.M. 1975. Growth responses to the formation of endotrophic mycorrhizas in Solarium, Leptospermum and New Zealand ferns, p. 391407. In: F.E. Sanders, B. Mosse, and P.B. Tinker (eds.). Endomycorrhizas. Academic, London.

Cooper, K.M. 1977. Endomycorrhizas affect growth of Dryopteris filix-mas. Trans. Brit. Mycol. Soc. 69:161-164.

Cooper, K.M. 1984. Physiology of VA mycorrhizal associations, p. 155-186. In: C.L. Powell and D.J. Bagyaraj (eds.). VA mycorrhiza. CRC Press. Boca Raton, Fla.

Dehne, H.W. and G.F. Backhauss. 1986. The use of vesicular-arbuscular mycorrhizal fungi in plant production: 1. Inoculum production. J. Plant Dis. Prot. 93:415-424.

De Rouin, N., M. Caron, and L.E. Parent. 1988. Influence of some artificial substrates on productivity and DRIS diagnosis of greenhouse tomatoes. Acts Hort, 221:45-52.

Giovannetti, M. and B. Mosse. 1980. An evaluation of techniques for measuring vesicular-arbuscular mycorrhizal infection in roots. New Phytol. 84:489-500.

Graham, J.H. and L.W. Timmer. 1984. Vesicular-arbuscular mycorrhizal development and growth response of rough lemon in soil and soilless media: Effect of phosphorus source. J. Amer. Soc. Hort. Sci. 109:118-121.

Graham, J.H. and L.W. Timmer. 1985. Rock phosphate as source of phosphorus for vesicular-arbuscular mycorrhizal development and growth of citrus in a soilless medium. J. Amer. Soc. Hort. Sci. 110:489-492.

Henny, R. J., J.F. Knauss, and A. Donnan. 1981. Foliage plant tissue culture, p. 137-178. In: J.N. Joiner (cd.). Foliage plant production. PrenticeHall, Englewood Cliffs, N.J.

Hewitt, E.J. 1966. Sand and water culture methods used in the study of plant nutrition. 2nd ed. Commonw. Agr. Bur. Tech. Commun. 22.

Johnson, P.N. 1977. Mycorrhizal endogonaceae in a New Zealand forest. New Phytol. 78:161170.

Johnson, C.R. and R.L. Hummel. 1986. Influence of media on endomycorrhizal infection and growth response of Severinia buxufolia. Plant \& Soil 93:35-42.

Menge, J.A. 1983. Utilization of vesicular-arbuscular mycorrhizal fungi in agriculture. Can. J. Bet. 61:1015-1024.

Menge, J. A., D. Steirle, D.J. Bagyaraj, E.L.V. Johnson, and R.T. Leonard. 1978. Phosphorus concentrations in plants responsible for inhibition of mycorrhizal infection. New Phytol. 80:575-578.

Mosse, B. 1962. The establishment of vesiculararbuscular mycorrhiza under aseptic conditions. J. Gen. Microbiol. 27:509-520.

Mosse, B. 1972. Effects of different Endogone strains on the growth of Paspalum notatum. Nature (London) 239:221-223.

Mosse, B. 1973. Advances in the study of vesicular-arbuscrdar mycorrhiza. Annu. Rev. Phytopathol. 11:171-196.

Nemec, S. 1987. VA mycorrhizae in horticultural systems, p. 193-211. In: G.R. Safir (cd.). Ecophysiology of VA mycorrhizal plants. CRC Press, Boca Raton, Fla.

Parent, S. and M. Caron. 1987. Soilless medium effect on the development of vesicular-arbuscular mycorrhizae on leek, p. 283. In: D.M. Sylvia, L.L. Hung, and J.H. Graham (eds.). Proc. 7th North Amer. Conf. on Mycorrhizae. Inst. of Food and Agr. PubI., Gainesville, Fla.

Parkinson, J.A. and S.E. Allen. 1975. A wet oxidation procedure for the determination of nitrogen and mineral nutrients in biological material. Commun. Soil Sci. Plant Anal. 6:111.

Plenchette, C., V. Furlan, and J.A. Fortin. 1982. Effects of different endomycorrhizal fungi on five host plants grown on calcined montmorillonite clay. J. Amer. Soc. Hort. Sci.107:535538

Powell, C.L. 1982. Selection of efficient VA mycorrhizal fungi. Plant \& Soil 68:3-9.

Rhodes, L.H. and J.W. Gerdemann. 1980. Nutrient translocation in vesicular-arbuscular mycorrhizae, p. 173-195. In: C.B. Cook, P.W. Papas, and E.D. Rudolph (eds.). Cellular interactions in symbiosis and parasitism. The Ohio State Univ. Press, Columbus.

Saif, S.F. 1977. The influence of stage of host 
development on vesicular-arbuscular mycorrhizae and endogonaceaous spore population in field-grown vegetable crops. I. Summer-grown crops. New Phytol. 79:341-348.

Saif, S.R. 1981. The influence of soil aeration on the efficiency of vesicular-arbuscular mycorrhizae. I. Effect of soil oxygen on the growth and mineral uptake of Eupatorium odoratum L. inoculated with Glomus macrocarpus New Phytol. 88:649-659.

Saif, S.R. 1983. The influence of soil aeration on the efficiency of vesicular-arbuscular mycorrhizas: I. Effect of soil oxygen on growth and mineral uptake in Eupatorium odorarum L., Sorghum bicolor (L.) Moench and Guizotia abyssinica (L. f.) Cass. inoculated with vesicular-arbuscrdar mycorrhizal fungi. New Phytol. 95:405417
Sanders, F.E. 1975. The effect of foliar-applied phosphate on the mycorrhizal infections of onion roots, p. 261-276. In: F.E. Sanders, B. Mosse, and P.B. Tinker (eds.). Endomycorrhizas. Academic, London.

Scott, A.J. and M. Knott. 1974. A cluster analysis method for grouping means in the analysis of variance. Biometrics 30:507-512.

Smith, S. E., B. J. St John, F.A. Smith, and D.J.D. Nicholas. 1985. Activity of glutamine synthetase and glutamate dehydrogenase in Trifolium subterraneum L. and Allium cepa L.: Effects of mycorrhizal infection and phosphate nutrition. New Phytol. 99:211-227.

Stamps, R.H. and C.R. Johnson. 1984. Vesiculararbuscular mycorrhizal inoculation and fertilizer level affect yield, morphology, chlorophyll content, water uptake and vase life of leatherleaf fern fronds. Proc. Fla. State Hort. Soc. 97:264-266.

Steel, R.G.D. and J.H. Torrie. 1980. Principles and procedures of statistics. a biometrical approach. McGraw Hill, New York.

Stolzy, L. H., J. Letey, T.E. Szuszkicwicz, and O.R. Lunt. 1961. Root growth and diffusion rates as function of oxygen concentration. Soil Sci. Soc. Amer. Proc. 25:463-465.

Sutton, J.C. 1973. Development of vesicular-arbuscular mycorrhizae in crop plants. Can. J. Bet. 51:2487-2493.

Warncke, D.D. 1980. Recommended test procedure for greenhouse growth media, p. 31-33. North Dakota State Univ., Fargo. North Central Reg. Publ. 221, Bul. 499.

\title{
Constant Soil Temperature Influences Flowering of Alstroemerias
}

\author{
Theo J. Blom ${ }^{1}$ and Brian D. Piott ${ }^{2}$ \\ Horticultural Research Institute of Ontario, Vineland Station, Ont., \\ LOR 2E0, Canada
}

Additional index words. rhizome, soil cooling, soil heating

\begin{abstract}
The effect of constant $16 \mathrm{C}$ and noncontrolled soil temperature on flowering of four Alstroemeria cultivars grown in a greenhouse was studied over 3 years. Soil temperature regime did not influence either the start or cessation of flowering. During spring/summer, production was $15 \%$ lower under constant soil temperature, irrespective of cultivar. During fall/winter, the effect of constant soil temperature was cultivardependent; yield of 'Red Sunset' was increased by $150 \%$, while that for 'Rio' decreased by 2270 relative to the noncontrolled. Annual production was not affected, but the ratio between the production of spring/summer and fail/winter decreased from 3.1 to 2.2 for noncontrolled and constant soil temperature, respectively.
\end{abstract}

Alstroemeria has developed worldwide importance as a cut flower crop due to excellent vase life, low energy growing requirement, and high productivity. Rhizomes are normally planted October through December in northern-latitude greenhouses. Production commences the following MarchApril and continues until June-July, when rhizomes cease to flower and produce primarily Vegetative shoots. A fall flush can be expected during October-November at lat. $56^{\circ} \mathrm{N}$ (Powell and Bunt, 1986; Vonk Noordegraaf, 1975a). This cropping pattern usually continues for 2 to 4 years.

The control of flowering is biphasic (Wilkins et al., 1980; Vonk Noordegraaf, 1981). Plants require a cold induction treatment (thermophase) as a prerequisite to flowering. This can be fulfilled by a short (4-week) pe-

received for publication 3 Oct. 1988. Project H86-2002. ICAR 86000243. We gratefully acknowledge the support of Flowers Canada. The cost of publishing this paper was defrayed in part by the payment of page charges. Under postal regulations, this paper therefore must be hereby marked advertisement solely to indicate this fact.

${ }^{1}$ Research Scientist.

${ }^{2}$ Agricultural Technician. riod at $5 \mathrm{C}$ or by progressively longer periods at higher (16 weeks at 13C) temperatures (Healy and Wilkins, 1982). Relatively high soil temperatures $(17 \mathrm{C})$ have also been shown to induce flowering (Vonk Noordegraaf, 1975b), while 22C stops flowering (Healy et al., 1982). The mechanism that triggers a flush once the thermtophase has been fulfilled is still unclear. However, exposure to a longday regime (photophase) induces earlier flower production than short days (Heins and Wilkins, 1979), but does not always increase total production (Vonk Noordegraaf, 1975b). Cessation of flowering after a flush is believed to be due to high soil temperatures, lack of plant growth substances (Heins and Wilkins, 1979; Healy and Wilkins, 1982), and/or long photoperiod (Healy and Wilkins, 1985).

Our study investigated the effects of soil temperature, maintained at an inductive level year-round, on start and cessation of flowering and total production. Flower production of four alstroemeria cultivars was compared using an uncontrolled and a constant $16 \mathrm{C}$ soil temperature year-round over 3 years.

Two adjoining $50-\mathrm{m}^{2}$ computer-controlled glass greenhouses, each with four ground beds, were used. The soil of one compartment was maintained at $16 \mathrm{C}$ set-point yearround by mixing and circulating either cold or warm water through 18-mm-diameter polybutylene lines; the soil temperature in the other compartment was not controlled. Soil temperatures were recorded at $15-\mathrm{cm}$ depth using "T" thermocouples and a Kaye Digistrip datalogger (Bedford, Mass.). In both compartments, bed areas were mulched with polystyrene beads, and the pathways were covered with straw. Air temperature was set according to commercial practices at a min-

Table 1. Annual yields in marketable stems $/ \mathrm{m}^{2}$ for noncontrolled (NST) and constant (CST) soil temperature during two seasons averaged over 3 years.

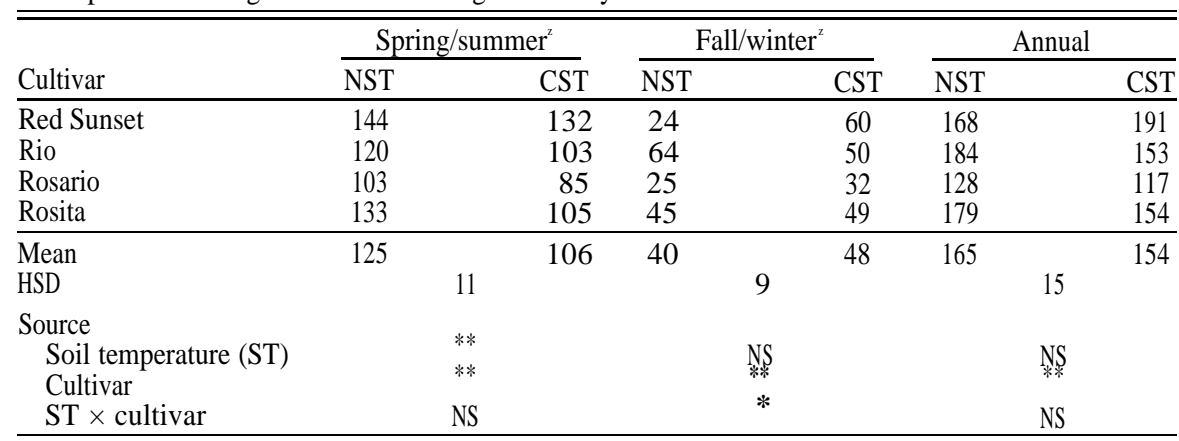

${ }^{2}$ Spring/summer (1 Apr.-30 Sept.); Fall/winter (1 Oct.-31 Mar.).

, *,** Nonsignificant or significant at $P=0.05$ or 0.01 , respectively. 